\title{
Estimated impacts of the sulphur directive on the Nordic industry
}

\author{
Esa Hämäläinen
}

Received: 3 September 2014 / Accepted: 24 February 2015 /Published online: 19 March 2015

(C) The Author(s) 2015. This article is published with open access at SpringerLink.com

\begin{abstract}
Introduction The International Maritime Organization and the European Parliament (EP) have stated that ships must lower sulphur emissions significantly in a specific region in Northern Europe, that is, in the Sulphur Emission Control Area (SECA), where sulphur content in bunkers is not allowed to exceed 0.1 percent. The Nordic companies have been examined somewhat marginally from the point of view of the SECA-directive, and how it will affect the cost-efficiency of the industry.

Methods The research data contains information about export to four large European countries that form the biggest markets in Europe for the case mill. The transport costs (freight costs per ton) were taken from the mill database on the customer level. The actual and forecasted mill data was copied into Excel spreadsheets for analysis.

Results Results of this case study strongly indicate that the sulphur directive has direct impacts to the economy of the Nordic bulk industry. When the bunker fuel prices increase from the year 2015 onward, it reflects directly to sea freight prices in the SECA-region. This will noticeably increase the total transportation costs per ton. The sulphur directive will be an additional cost burden for the Nordic industry, which in turn is something that from 2015 onward local European paper mills and other manufacturing industries will benefit from. Conclusions The sulphur directive will probably indicate that from 2015 onward Central European paper mills and other manufacturing industries will benefit from outside the traditional business environment. The impacts of the sulphur directive will vary heavily from market to market and transportation costs from Finland to Europe can increase by average more than 20 percent in $€ / t$; this can also be an underestima-
\end{abstract}

E. Hämäläinen $(\bowtie)$

Brahea, Centre for Maritime Studies, Kotka Unit, University of Turku, Heikinkatu 8, 48100 Kotka, Finland

e-mail: esa.hamalainen@utu.fi tion. Profitability can drop by tens of percentage due to more expensive logistics. Logistics costs' percentage in turnover will increase in the Nordic countries, but existing low oil price (2015) will mitigate the expected price increase of the MDO in the near future.

Keywords Sulphur directive - SECA · Paper industry · Transportation $\cdot$ Costs

\section{Introduction}

The European Commission [25] has stated in the White Paper of Transportation that the current oil-dependent transportation logistics must decrease emissions noticeably in the future. Especially the greenhouse gases (GHG) should be at the level of 60 percent by 2050 (compared to the situation of the year 1990). The latest published Green Paper addresses that the target value in the GHG emissions should be a 40 percent reduction by the year 2030 to be cost-effective. The European Commission (2014) announced that there is a broad consensus that interim targets for GHG emission reductions will be necessary in order to reach the aspired 80-95 percent reduction by 2050. The directive has a substantial amount of positive impacts on nature and people's health, yet it also affects negatively on the Nordic bulk industries in the near future, since production and ship bunkers have to be adapted to be emission-free as required in the made decisions. The increase in fuel costs is to be expected.

The purpose of this empirical case study is to examine and anticipate in detail how these environmental directives affect the economic performance from 2015 onward, when the emission restriction directives come into effect. We will research how transport costs behave in the new bunker fuel situation, and how its factors influence the profitability of the paper mill under our study. As it is done from the viewpoint of a large 
exporting mill, this survey may help better understand how emission reductions stated by the European Commission [25] and the International Maritime Organization [38] can speed up an economic transformation in the Nordic export industry. Generally, the paper industry as a topic has been researched rather marginally in the Nordic countries from the perspective of the environmental, economic and transportation aspects put together. Only a few papers in Nordic research journals have been published under aforementioned disciplines (see e.g. [35-37]).

Dennis and Berry [16] highlighted that in order to achieve significant improvements in environmental conditions, all participants in a multimodal transportation network must identify potential environmental impacts caused by their activities, monitor their environmental performance, and control or prevent environmental damage through proactive environmental practices. In their case study, Wuisan et al. [66] claim that the existing IMO regulations on marine protection are not sufficient enough to uncouple growth in shipping from environmental harm. Even though the focus is no longer limited to safety and oil spills, ambitious standards are still lacking, and it may take years before new regulations are adopted and fully implemented. Wuisan et al. [66] express that enforcement of regulatory standards will remain a problem as long as there are no incentives for shipping companies to invest in the best available techniques and environmental management.

The fact is that ship operations emit into air many types of pollutants such as nitrogen oxides, col dioxide, sulfur dioxide, particulate matter, and other hazardous elements. From a shipping company's viewpoint, aiming to minimize bunker consumption (which reflects on emission) has two implications: international or local regulations on ship emission must be fulfilled as well as an image of social responsibility constructed. In order to take emission into account in modeling, one can approach it by minimizing the weighted sum of operating costs and emissions [63]. Ship transportation has been considered to be the most environmentally friendly transport mode when compared with other modes globally. Yang et al. [67] note from a Taiwanese angle that internal green practices and external collaboration have positive impacts on green performance, which in turn helps to enhance company competitiveness. However, this comment has no relation to fuel costs, which form a larger part of ship operating costs.

Paper products are transported to the large export countries by using obligatory short sea shipping (SSS). There is no possibility to use any other modes because Finland is an island from the perspectives of export; 90 percent of the exports are using the SSS. Therefore the alternative modes were left aside as to the purposes of this study. In particular, bulk products are transported to the European main markets by the sea (SSS). To the eastern markets, such as Russia, paper products are usually transported by trains. According to a study made by the University of Turku, shipping companies showed that 90 percent of ship owners will use MDO from 2015 onwards. However, there also are other fuel solutions such as retrofits to older ships; so-called scrubbers with HFO, and liquid natural gas (LNG, in one ferry ship, but several retrofits and new ones are under construction). Methanol with some modifications and slow steaming are also usable [33]. However, for several years ahead, marine diesel $(<0.1 \%$ in the SECA $)$ will be the best fuel solution for vessels.

Song and Dong [55] addressed in their interesting contribution that there is a decent amount of free time and ineffective waiting due to insufficient vessel capacity; empty containers may be unavailable, temporarily storing laden containers may cause demurrage at transshipment ports, there may be an empty container inventory at ports, or empty containers may be transported. Drewry [17] notes that repositioning empty containers has been a huge burden for many shipping lines, and that the containers have accounted for at least 20 percent of the global port handling activity 1998 onward. It was estimated that the cost of moving empty containers around the globe exceeded US\$15 billion in 2002 [56]. These unnecessary actions also produce extra costs and substantial environmental emissions, but there are some challenges in minimizing the movement of an empty container due to imbalances in global trade volumes between different countries and continents. Lindstad, et al. [43] demonstrate in their contribution that significant cost and emission reductions can be achieved by varying speed as a function of sea conditions and freight market. In their model they show that in combination with accurate weather data, voyage routings that give significant cost and emission reductions can be defined. Lindstad et al. [44] present a daring argument in their paper stating that emissions can be reduced by up to 30 percent at a negative abatement cost per ton for $\mathrm{CO} 2$ by replacing the existing fleet with larger vessels. However, replacing all vessels can take as long as 25 years, so emissions reduction will be achieved gradually as the current fleet is renewed. The argument is based on the idea that the existing HFO bunker fuels would be used, thus it is rather theoretical when evaluating it from the point of view of the existing situation now in 2014. However, there are also other solutions such as retrofits to old ships; so-called scrubbers with HFO, and LNG (one ferry ship, but several retrofits and new ones under construction). Methanol is also usable with some modifications, and slow steaming will be used in the Baltic Sea [33]. However, the marine diesel with low sulphur fuel will be the only real solution for several yars to come.

As international organizations, the International Maritime Organization [38] and the European Union [23, 22] have taken active roles in leading marine environmental discussion in emission regulation. As a consequence, the European shipping industry must substantially reduce air emissions. Decision makers, that are politicians, have realized that neither constructing environmental images for shipping companies 
or voluntarily controlling and reducing marine transportation emissions do not happen so easily, and this is due to cost increases vs. heavy global competition between cargo shipping companies.

In this study we will mainly focus on the following topics:

- How will the sulphur directive affect sea freights and transportation costs in 2015 in the SECA-region for a company and its markets?

- How will changes in logistics costs affect profitability, separately in four large market areas (countries)?

In this study, the main research topics, logistics and transportation, are understood as synonym; they are seen as a process in which the wrapped paper products are transported from a mill warehouse to customers, particularly in the four case European countries by multimodal means. All costs and prices have been calculated separately for all of the four markets to expose the interesting variations between the market areas.

The structure of the paper is as follows: Background information about the environmental marine directives and environmental regulations in ship transportation, which contributed to the ideas in this study, is presented in section 2. In section 3 , a general look at the sulphur directive's estimated cost consequences to transportation is taken. The used case study methods, origin of the data, as well as data mining and its methods are described in section 5. The detailed results, which are based on an empiric data analysis, are presented in section 6. Discussion and conclusion are summed up in section 7 and we also introduce some future research topics concerning the paper industry in the Nordic countries.

\section{Discussions on marine environmental directives}

The IMO [38] and The European Parliament [23, 22] have stated that sulphur emissions from ships must be reduced significantly in Europe to achieve lower engine inherited emissions. Therefore, the definition of the Sulphur Emission Control Area (SECA) stated by the IMO is one clear example of such environmental actions which will deal in aforementioned means with all ship transportation companies sailing in that control area. The Sulphur Emission Control Area also covers the whole Baltic Sea, and the regulation will come into effect 1st January 2015 (Fig. 1). As a result, impacts to nature and humans should be clearly positive, because in the Control Area bunker fuel sulphur content will be max. 0.1 percent, ten times lower than the existing limit of 1.0 percent.

Ships entering this area must change bunker fuel to the clean Marine Diesel Oil (MDO) or have a combination of the HFO and scrubbers, which remove extra sulphur from bunker fuel. Moreover, the ships can use environmentally friendly Liquid Natural Gas (LNG) as fuel, if their engines

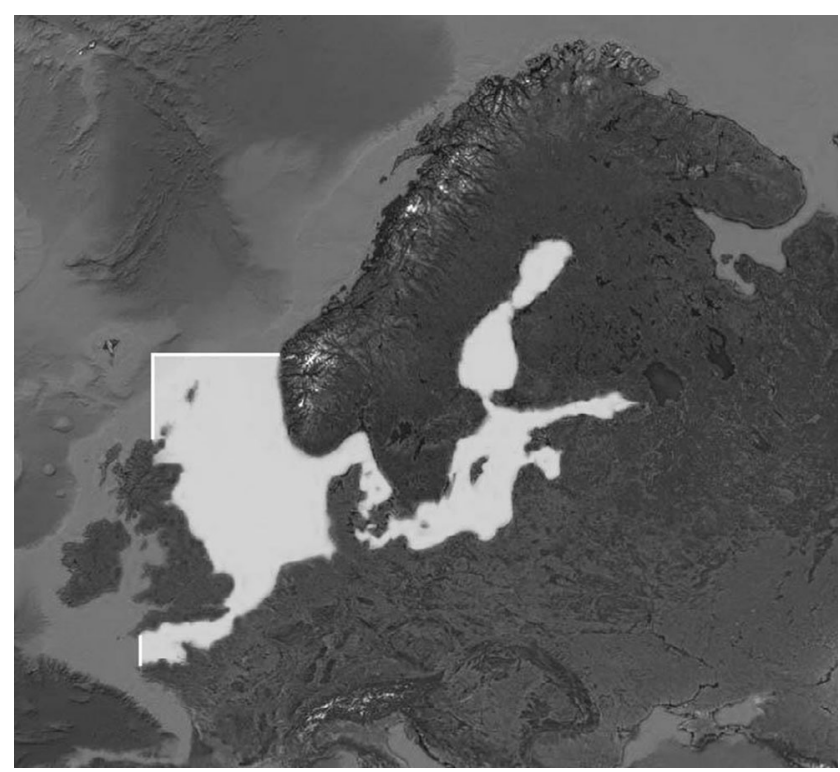

Fig. 1 Sulphur emission control area (SECA)

are modified to use it, yet this is not common according to Acciaro [1]. The World Shipping Council [65] addresses that international marine transportation produces round 870 megatons of $\mathrm{CO} 2$ emissions, which is about 2.7 percent of the emissions made by human activities (total amount 32222 megatons) in 2007. The European commercial marine transportation in the SECA-region produced about 40 megatons of $\mathrm{CO} 2$, which was circa 4.6 percent of the global marine transportation. Container ships account for approximately 25 percent of that amount, and they are moving roughly 52 percent of the maritime commerce by value. For a typical container ship 2000-2999 TEU, operating in the SECA-region in the Baltic Sea, emission factor is $20 \mathrm{gCO} 2 /$ tonne-km compared with road transport's $62 \mathrm{gCO} 2 /$ tonne-km [14]. The Nordic exports are therefore transported by relatively environmentally friendly means even if the transport routes are rather long to main markets.

Hulskotte and Denier van der Gon [32] present in their study that seagoing ships at berth consume considerable amounts of heavy fuel oil as opposed to the expectation that fuel consumed at berth would mainly be distillate fuel. This in turn results in higher emissions than are expected, based on the assumed use of low-sulphur fuels. In the SECA-region these emissions at ports will be reduced substantially, because the HFO will not be allowed anymore.

Currently, vessels in the Baltic Sea can use bunker fuel that has the maximum of 1.0 percent sulphur content, so the new limit value is ten times less than the existing level. In addition to the MDO, there are cleaning systems based on scrubber technology, in which the sulphur is washed from heavy bunker oil in a complicated process. However, the technology is not yet been considered to be mature and reliable enough. Moreover, the final operating costs of the scrubbers have not 
been studied sufficiently enough (see e.g. [11]). Understandably, several ship owners worry that the scrubbers will not work reliably, especially in the Baltic Sea, where the salt content is very low, and that it will be hard to make the chemical cleaning process certain. It has been argued that in continuous use in the Baltic Sea, scrubber technology will remain unreliable due to chemical and technical challenges. Moreover, maintenance of these installations is quite costly and "the scrubbing process" needs continuous control at the sea. Even if the ship-owners made retrofits and used closed scrubbers, the waste must be left at the ports, and this will add costs. This concrete and mistrustful view towards scrubbers can be found from the latest survey of The Ship Owners Barometer covering 262 ships operating in the Baltic Sea [5]. The ship owners announced quite clearly ( $88 \%$ of answers) that they are going use the MDO as bunker fuel in 1.1.2015. This indicates a substantial increase in fuel costs in the Baltic Sea Region, as well as higher sea freights. Certainly, these roughly estimated price differences go hand in hand with freight unit costs in the Baltic Sea region. However, the variation of impacts will definitely be wide due to differences in the export industries. Figure 2 addresses how the oil price has developed during 2001-2014. The price has remained at quite a high level until summer 2014, when the oil prices started to lower very quickly down to 60 USD. In 2001, the average oil price was about 20 USD per oil barrel, and in 2008, at its highest level, about 140 USD per barrel. Due to shale oil production, the United States has brought shale gas to market and is also exporting a substantial amount of it, and this has probably prevented oil price from increasing, as did happen during 2001-2008 [6]. The effect of oil prices on shipping can be directly translated into increased bunker costs, whereby fuel costs represent as much as 25 to 60 percent of the total operating costs for a ship, depending on its type and services [47].

Æsøy et al. [8] and Acciaro et al. [2] address that costs, availability and technical maturity appear to be the most critical issues for the success of LNG as a maritime fuel on a larger scale. The LNG is a solution for the future, because engines need be modified for this type of fuel, or new fleet built from one vessel to the next. It is good to remember that bunkering of the LNG is not possible at the moment, other than in rare places in the Baltic Sea region. Nevertheless, it is expected that in the future a substantial amount of ships will be built to use clean LNG as fuel, and the type can be considered to be environmentally sustainable then as well. However, the LNG usage will also be dependent on which price levels will subside on the long run. Acciaro [1] note that although investing in the LNG is not economically sensible as of today, even in the case of the stringent ECA regulation, a valid strategic option is to defer the investment decision and gain a better insight into the development of the fuel market. Depending on the remaining economic life of a vessel, technological developments, and change in fuel differentials, deferring investment in the LNG to the near future might be an optimal strategy. Acciaro [1] point out that nowadays only a handful of vessels use LNG, in addition to approximately a hundred LNG-carriers. It is obvious that such new technology, when compared with some 100000 diesel-fuelled ships, is yet to reach its full maturity, even though the SECA regulation may have an effect on favoring the LNG technology development.

The SECA-decision will increase discussions among the Nordic export industries about new, alternative and relevant multimodal transport routes, which will be cost-efficient and capable of handling and transporting large cargo volumes regularly. One possible new export route from Finland could be
Fig. 2 Development of the oil price 2001-2014 [19]

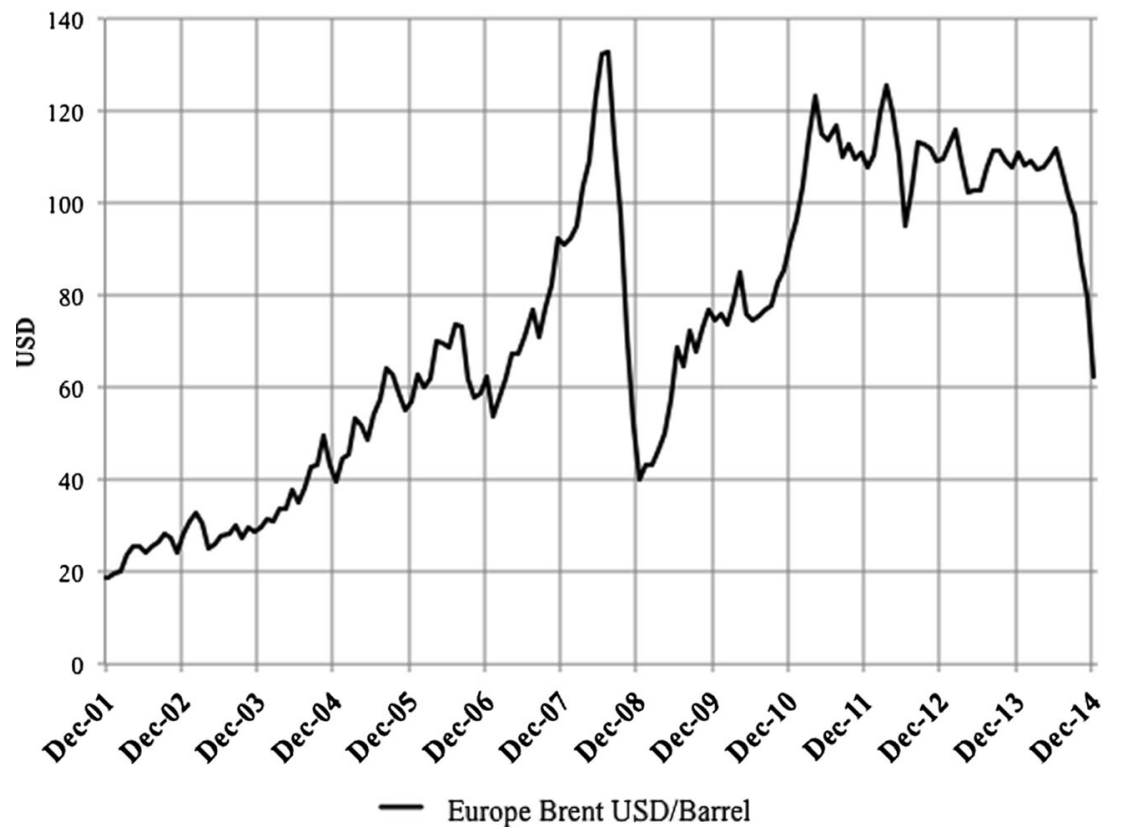


the railway connection Baltic Corridor from Tallinn to Warsaw (AECOM [3, 4]. Hilmola [29] addresses that as to sea and rail routes, there are peculiarities in the Baltic Sea Region, and thus it would seem that dominance of road continued. Hilmola argues that the aforementioned is caused by an additional cost burden (railway payments and sulphur restrictions to sea) covered by these two alternative modes. Thus, the amount of funds gathered through environmental and infrastructure payments increases, yet it is not likely that these alone would change modal shares. Relevance of these new routes should be anticipated carefully. Accurate forecasting has failed being strong. Instead, it has been a real challenge, especially for the Finnish paper industry [36].

Some researchers have forecasted that large cargo volumes could be transported through the Arctic ports (e.g. Murmansk), yet for example, container handling in the port of Murmansk is not really a realistic option at the moment [50]. This route from Rotterdam to Sanghai is 30 percent shorter than the one through the Suez channel. The usage of the Northern Sea Route (NSR, called from Russian perspectives) has increased substantially during the last year, and the trend is rising, yet volumes are still slow. In their interesting system dynamicity model, Hilmola and Lorentz [30] examined the role of confidence, and how actions of authorities can make disruptions in well-functioning supply chains inside a very short time period. Therefore, the new transport routes should be examined carefully beforehand from a managerial point of view. Volumes in a bulk industry, such as paper manufacturing, are huge, and there have been forecasts about the continuously lowering demand in the Western European markets, so new markets and growing Asian markets and routes interest the Nordic export industry substantially.

\section{Anticipated cost consequences of the sulphur directive}

The MDO price levels in 2015 have been under discussions, lately especially in the Nordic countries, because of the SECA-decision. Experts have presented many forecast calculations in order to anticipate a correct MDO price-level for 2015 [59, 21, 60]. Problematic for logistics providers is that there are large variations in these MDO-price estimations. For example, Notteboom et al. [47] claimed in their study that the price of the MDO could increase from 25 percent up to 200 percent in 2015 in comparison with the existing bunker prices. Analogically to the previous articles, the European Maritime Safety Agency [21] crystallized in their forecasting study how the sulphur directive can impact marine transportation in the SECA-region:

1. The MDO will be more expensive (prediction: about 60 $70 \%$ more expensive than $1.0 \%$ of oil; price difference largely the same).
2. Modal shift implications uncertain; some short sea routes may be affected, also in the Baltic Sea.

3. Wider benefits for environment and health; rules are clearly cost-effective.

4. Scrubbers and the liquefied natural gas (LNG) are feasible and cost-effective alternatives as fuel solutions; however, the timetable is open.

5. Medium-range routes will to be affected harder, general cargo and container ships as well, and low-value goods will be more vulnerable to fuel price increases.

These realistic comments from the EMSA are anticipating logistics challenges in the Northern Europe, because availability of alternative transport routes and means is very limited. The impacts of the SECA can vary substantially from industry to industry, and from market to market as well [34]. Moreover, the positive impacts received from feasibility studies have not convinced the Nordic stakeholders (see e.g. [59]). The problem is realized when fuel prices are compared. Recent raw oil price development in the second half of 2014 and at the beginning of 2015 has been very positive from ship-owners' perspective: price of oil barrel is round $50 \mathrm{USD} /$ barrel [49]. How long this development will last, and how will it impact the MDO prices are largely uncertain. The current price of the MDO (0.1\%), according to Bunkerworld [13], is circa $600 \$ /$ $\mathrm{mt}$, and compared with the HFO price (1.0\%) $335 \$ / \mathrm{mt}$ thus nearly 100 percent more. Nevertheless, this existing low oil price will strongly mitigate the expected price increase of the MDO in the near future. Furthermore, there are strong arguments seen from long-term perspectives that the oil price will start to rise again in the coming years [49] due to a strong global demand, especially in Asia.

The Swedish research company Sweco [58] has forecasted a total drop of 9 percent in demand for freight transport in Sweden for 2015, mainly due to the SECA decision. The company anticipates that demand for maritime freight transport will fall by 21 percent, and heavy road transports by 8 percent, while still expecting rail freight transport demand to increase by 11 percent. The total drop in freight transport demand would be dramatic and similar in comparison with the 14 percent fall in demand after the financial crisis during 2008. Overall in the Nordic countries, the cost impacts to the whole export sector logistics chain from ports to sea freights will be large, and the cargo volumes lower. The existing service providers in the logistics chain have to compete more heavily in the logistics market. The sulphur directive may in the long run change the industrial structure in the Nordic regions from heavy products to lighter and more expensive ones per weight unit.

The SECA-decision and transportation together are an interesting research topic. The 2008 Nobel Prize winner, Krugman [41] addresses that in a world characterized by both increasing returns and transportation costs there will be an 
obvious incentive to centralize manufacturing close to the largest market. The simple reason for this is that by locating the production near the larger market, one minimizes transportation costs. The SECA-decision has already influenced the regions in question, especially exporting companies that are not static entities. The SECA-directive has addressed that the business environment can radically and quickly be transformed with decisions made by the EU Parliament, not only by demand development or changes in consumer behavior.

A challenge also rises from estimating the supply-demand balance of the different distillates such as the MDO and the HFO in the European markets. The Swedish Forest Industries Federation [59] is concerned that these environmental directives are unfair to the Nordic industry, and as a result, the sulphur directive may have serious impacts on the competitiveness of the Northern European heavy industry. A representative group of British marine, industry and logistics researchers addressed its concerns in a critical report [31] noting that as an economic impact on all marine traffic in the SECAregion, the sulphur directive may bring heavy additional costs. We have to keep in mind that from 80 to 90 percent of the Nordic industry production is transported to Europe through short sea shipping routes, which go through the SECA-region.

\section{Background for the case study}

The impacts of the SECA-decision will be estimated through the case data, which was obtained from one large paper mill located in Finland. Yin [68] addresses that there is a distinctive demand for composing case studies, because there is a need for understanding the complex phenomena. The complexity refers to something which is otherwise difficult or impossible to understand. It can be rather challenging to research how an environmental decision, such as the SECA, affects an export industry's economy without a case study. Case studies are preferred in studying contemporary events where relevant behavior cannot be manipulated [68]. Therefore, the results can be considered reliable and generalizable to some scale, yet not necessarily seen as statistical samples. Case study can be either quantitative or qualitative or a combination of both, which means that the research data can be either numeric or systematically classified qualitative data with no numeric values [28]. Case studies are often done for a specific target group, whose knowledge and understanding of the phenomena the study aims to increase [57]. This is a natural and relevant observation, because all sciences usually have their own audiences and research journals to publish studies in. Eisenhardt [20] defines a case study as "a research strategy, which focuses on understanding the dynamics present within single settings. This refers to the situation where things are under constant change and a case study offers a possibility to examine impacts of the change." According to Easton [18], case studies offer the possibility of exploring specifically defined problems which otherwise could be difficult to examine. Because a case study is not a sample in the statistical sense, the expression of uniqueness is important to understand [53]. Generalizations are not easy to make. The researcher should be aware the type of a case the objective of the study is: critical, typical, unique, revealing, future-oriented, extreme, or longitudinal [26, 68]. Lewis [42] considers that iterative triangulation employs systematic iterations between literary review, interviews, case evidence, and intuition. Flyvbjerg [26] notes that case studies can provide microeconomic discoveries, which cannot be acquired through other methods [45]. Ballou [9] reminds that the acquisition of correct and reliable data is crucial to the successful practical application of any model. Even the best model, if implemented with incorrect data, will produce false supply/demand chain configurations. According to Baxter and Chua [10], one of the greatest practical challenges in making a case study research is the lack of access to reliable data. Yin [68] highlights that conducting a case study lies in the desire to reveal complex conditions. The case mill, as all Nordic mills, deliver manufactured paper tons to markets where they are able to sell their products in the lowering trend. The selected four research countries do not have measurable reciprocal effects or dependencies in the paper deliveries. All economic figures are presented out for research purposes. Due to reliable and valid data from the case mill, this examination gives an opportunity to make certain generalizations about the research results and contribute to the supply chain costs research concerning the Nordic paper mills.

\section{Paper mill as a research target}

In this paper, we utilize the mill data to present the impacts of the environmental regulations on the Nordic industry, because the forest sector is still one of the key industries in Finland and Sweden. Since 2002, the Nordic paper mills have been facing particularly challenging times as to their existence and operation [36]. The paper companies have closed over 30 machine lines in Finland, including several paper mills [36]. During the past 10 years, the economic situation in the Nordic paper industry has been affected by the lowering demand and overcapacity [36, 27].

Hämäläinen [36] addressed that there are heavy fluctuations in paper deliveries at customer levels, and these variations make logistics planning rather difficult. Intermediate warehouses must be utilized, which is probably one reason for long warehousing times [40, 39]. However, observed from the logistics point of view, the Nordic countries have built well-functioning transportation systems when compared with many other countries located in Europe (World [64]). A probable reason for this is the long tradition of sea freight transportation in the Nordic countries year-around, from icy to free 
water conditions. The value of forest products was approximately half of the total exports in 1995 , and in 2013 , it was still around 20 percent [27]. In many Finnish rural areas, timber harvesting companies together with local paper mills are still some of the most significant employers. The mills are located mainly in the southern parts of Finland and close to ports, and they need multimodal transportation means to transport paper products to the European markets. The EU market is fairly large, immensely concentrated, and behind a short sea route when analyzed from the Nordic logistics perspective. The Nordic paper mills are normally integrated sites, which consist of pulp processing, paper manufacturing, and a complex mixture of converting, warehousing, transportation and cost management functions. This value chain covers the process functions from timber yard to end customers ([35, 36] and c).

Paper export from the Nordic countries to the European markets occurs in many stages: storing at a mill's warehouse, a short domestic truck or train transportation to a domestic port, a short sea transport, intermediary converting and repackaging, intermediary warehousing, and finally, local transportation to customers. The paper rolls are normally put in containers at the port when taking products to these four countries. The transport costs (freight costs per ton) were taken from the mill database on the customer level.

In Europe, there can be several distribution centers, where consignees pick up their rolls when they are needed in printing production. Many Eastern European printing houses or wholesale firms can pick up their paper packages directly from a paper mill by a semitrailer truck, and transport products by roads to their own warehouses [36].

The Nordic paper machines could stay in competition by being efficient in the overall logistics, and Hämäläinen [36] addresses that faster transit operations in warehousing could easily generate direct cost savings amounting to 2-4 percent in annual turnover. However, the SECA-decision will threaten logistics processes due to increasing costs in the essential transportation component, bunker fuel, which in turn have direct impact on sea freight costs.

\subsection{Case data and the forecasting method}

The target of this research study is a paper mill located in Southern Finland, quite close to an exporting port. The site manufactures all of its products locally, but acts very globally because of the export dependency; it transports its final products mainly to the European markets $(70 \%)$, and about ten percent to domestic customers. The longitudinal data covers the period between 2001-2009, and the authors obtained it from the case mill's cost management SQLdatabase (see $[35,36]$ and c). This quantitative database stores the mill's past and present production, economic and logistics information, which is controlled by official authors.
All the statistics are reported in the mill's annual economic reviews. The database covers fixed and variable costs as well as geographical aspects, such as transportation costs and paper prices to points of destination. These figures have been transformed into a single large dataset, and it is based on packed net tons and euros. The parameters are calculated mainly in $€ / t$ or in percentages, which gives the possibility to make relevant comparisons. The results of the calculations are shown as ratios to maintain business confidentiality. The key objective is to determine the relevant value-added factors. From the viewpoint of triangulation, a number of discussions with the logistics management of the case mill as well as with mill management of another large paper company were carried out. These discussions helped significantly in focusing the research on relevant topics. The research data contains information about export to four large European countries that form the biggest markets in Europe for the case mill. The transport costs (freight costs per ton) were taken from the mill database on the customer level. The paper rolls are usually put in containers at the port when taking products to these four countries. The ships can be either Ro-Ro ships or containerships depending on the shipping line. The countries are all coastal countries to which the mill's paper products are transported from Finnish harbors by short sea routes.

The method is presented below to show how reliable research data was generated for forecasting calculations in order to simulate the situation in 2015 :

1. From the dataset acquired (years 2008-2009) we forecasted transportation costs for 2015. From the Nordic countries to Europe, the transportation costs correlate strongly with oil prices, and we estimated the costs to be at the level of 2007. The forecasted oil price for 2015 [13] gives a relevant and reliable base for this assumption. Naturally, the recent development of oil prices diminishes the pressures to increase low-sulphur fuel prices.

2. We also compared and reflected the mill quality paper prices with the prices from the Official Statistics of Finland [48] and the RISI [51], which both present the latest market paper prices in Europe. The prices have stabilized at the level of 2008-2009.

3. We calculated and estimated the variable and fixed costs by utilizing the Finnish official statistical data series from 2000-2014 and the mill values from 2009. Figure 3 shows that the Finnish paper mills have been able to stabilize manufacturing costs on the 2008 - 2009 level. Interests and depreciations are estimated to remain at the same level as in 2009 during the whole research period, thus these have no impact on profits. So in our simulations, when forecasting impacts bunker price as well as logistics and sea transportation costs have on profits and turnover, we have assumed that fixed and variable costs in total 


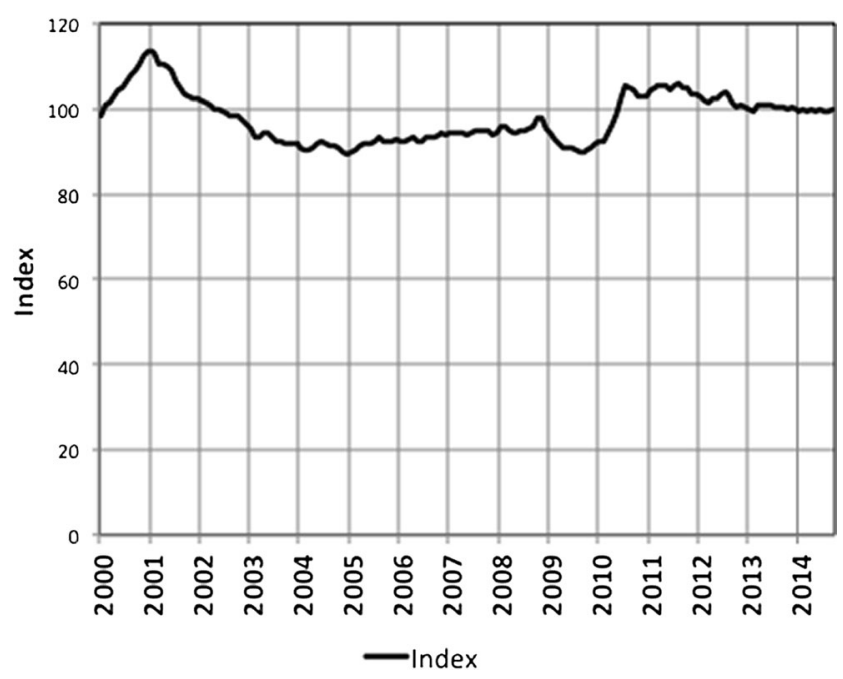

Fig. 3 Development index of the manufacturing costs during 2000-9/ 2014 in the Finnish paper mills. Source: [48]

have not changed. The official statistical figures also demonstrate and support this argument. Of course there is obviously variation between paper mills. When we obtained the fresh sales prices from the RISI [51] we noticed that sales prices of qualities made by the case mill were also at the same level than during 2007-9. Moreover, these topics were checked by the interviews with the case mill financial manager and production managers. Therefore, bunker prices, and thus transportation costs, have been estimated to have direct impact on mill's profits and turnover.

Schinas and Stefanakos [52] wisely caution to avoid making planning in the marine sector based on statistical assumptions or historical data. In this study we have utilized the historical data of one mill to a certain extent. We modified these figures with forecasting tools and methods in order to estimate price values and demand in 2015, based on articles provided by the Official Statistics of Finland, forest and oil industry experts, and on the development of transport indexes.

The actual and forecasted data was copied into Excel spreadsheets for analysis. In the datasheets we calculated the anticipated values, and thus created the figures. In our analysis we focused on how transportation costs and sea freights impacted profitability. All economic figures were reported out in ratio, for research purposes only. By using real data, our study attempts to estimate how the sulphur directive (in the SECAregion), as a new cost function, will impact logistics costs, and thus profitability of the Nordic case export company. The authors of this study try to reveal how the decisions of the European Commission as an environmental lawmaker, with a purpose to lower sulphur air emissions, can impact economic performance at company and market area levels.

\section{Findings and results}

In this section, by using the empirical research data we reveal how the recent environmental decisions (see [23, 22], European Commission 2014, [38]) can impact the Nordic export industry. Since the results received from the case data have been generalized, we remind the reader to be cautious. This is because generalization must be based on theory too, not just the results received from the case data.

Our research data was obtained from a typical export mill located in the countryside in Finland, behind multimodal logistics phases. The case company is exporting around 90 percent of its total production by using truck/train - short sea shipping - truck modes to get its products to the European markets. The European market covers about 70 percent of the total sales of the mill, and the four countries represent about half of the deliveries to Europe. Figure 4 highlights how transportation costs $(€ / T)$ to the four large Western European countries have developed on country-level from 2001 to 2009. When comparing transport cost development to oil price change (Fig. 2.) we can note that the trend is rather analogue. By averagely, the increase in transportation costs is less than 20 percent, even though the variation is large between these four markets due to different modes and modality. Country 1 is actually located the closest and country 4 the farthest from the mill, when distance is measured from the export port to the destination port through sea routes. Figure 5 addresses that the cost development has been very different marketwise if one compares it in percentages from 2001 to 2009 . The transportation costs to country 3 have increased heavily, over 50 percent since 2001. On the other hand, transport costs from Finland to country 2 have varied annually, yet in the end remained on the level of 2001. One reason for this low increase of transport costs is the quickly diminishing paper deliveries from Finland that have gone down from 10 million tons in

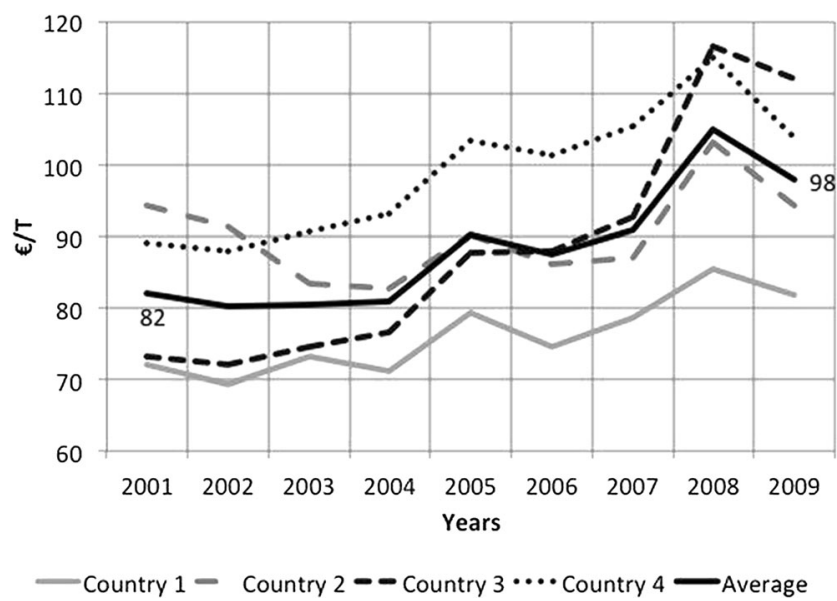

Fig. 4 Development of the transportation costs to the four export countries separately and in average 2001-2009 


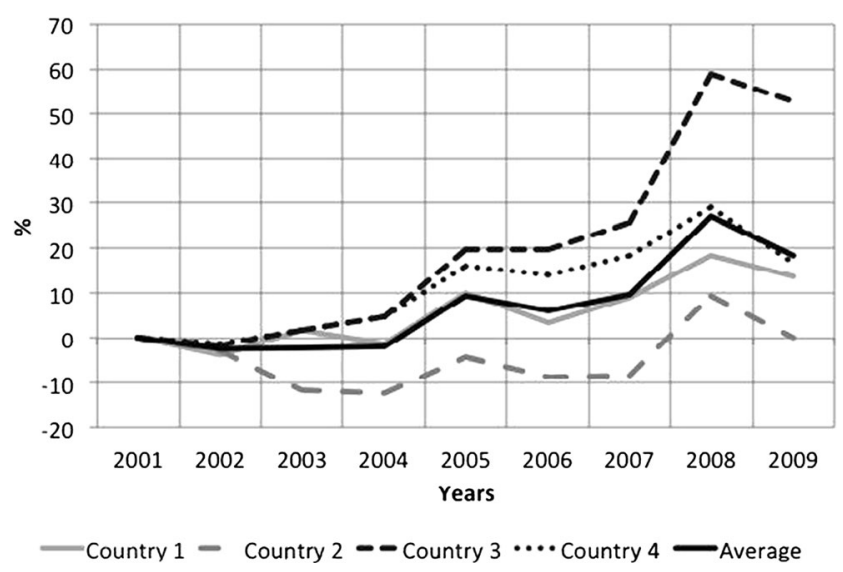

Fig. 5 Development of the transportation costs to the four export countries separately and in average 2001-2009

2006 to the estimated 6,5 million tons in 2013 [27, 62]. The sea transportation route to the country 3 is the longest, and there are several multimodal transport means. Moreover, the bunker price increase had been heavy since 2001. In the longer sea routes from Finland there are less competition between shipping companies. The aforementioned observations were the main reasons that the total transport costs increased heavily. The impacts of bunker costs on country 2 were not severe because the sea route is much shorter and there is heavy competition between shipping companies due to lowering freight volumes. In these markets, the logistics firms, such as truck and sea freight companies, have to fight fiercely with each other for the reduced and remaining cargo volumes. This has partially helped in keeping transportation costs at a relatively low level for some markets (country 2).

Several experts have forecasted that the price of the bunker fuel MDO containing max. 0.1 percent sulphur will be as much as 100 percent more expensive than the HFO per metric ton. However, we heavily doubt that the MDO prices will double. The future indexes support this opinion (see e.g. [15]). Figure 6 presents a simulation where the transportation costs per ton have been forecasted, assuming that the price of the MDO will increase from 0 up to 100 percent from the present state. As background information, Notteboom et al. [46] have examined that the percentage of a ship's fuel costs out of its total operating costs vary heavily depending on the ship type (25-65\%). In our forecasting calculations we have used 45 percent as cost-coefficient. Transportation costs from Finland to Central Europe include sea freights, which are circa $3 / 4$ of the total transportation costs per ton [34]. Based on our mill data, we have assumed that the total logistics costs, for example, are $100 € / \mathrm{t}$, and the total sea freights are 75 percent of the logistics costs, thus $75 € / t$. Thus other costs, such as port and land transport costs, are $25 € /$ t. Therefore, if fuel costs are 45 percent of a ship's costs we can assume that these constitute round $33.75 € / t$ of sea freights. Hence, if fuel costs increase by 50 percent when changing from HFO to MDO, then they (sea

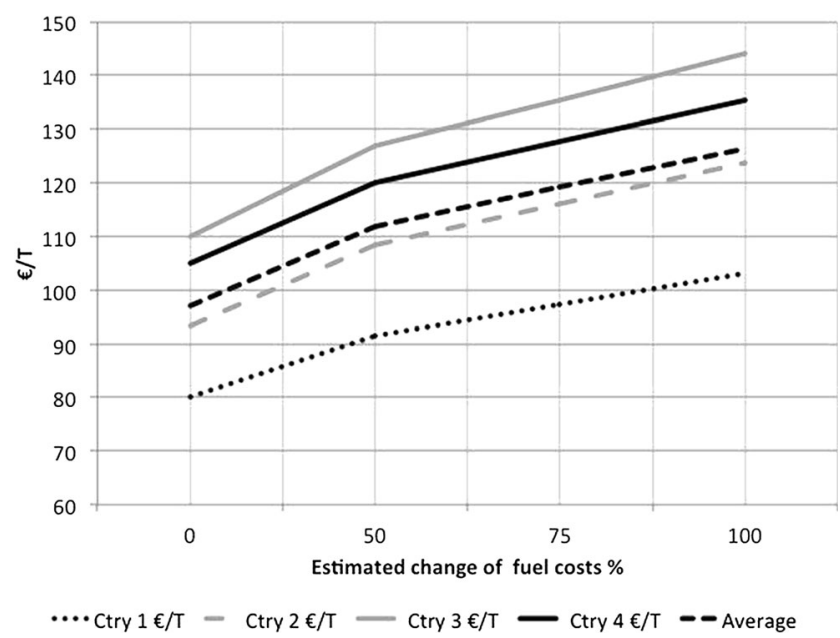

Fig. 6 Forecast of the transportation costs $(€ / T)$ if bunker fuel (MDO $0,1 \%$ sulphur content) price increases from 0 to $100 \%$

freights) will increase by $16.88 € / t$, and thus total logistics costs will be $116.88 € / \mathrm{t}$.

In Fig. 6, the starting value is anticipated to be the price in 2015 with no impact from the upcoming SECA-directive. Figure 6 shows how the increasing price of low sulphur bunker fuel will strongly affect the transportation costs per ton. Naturally, prices increase differently in various markets due to transportation modes, distances and sea freight volumes. If the estimated MDO price increases in the SECA-region, as e.g. Notteboom et al. [47] and Trafi [60] anticipate, impacts could be severe for the Nordic export industry. These inevitable cost increases in the whole logistics chain are not easy to eliminate by increasing sales prices in the paper industry [48].

In Finland the logistics costs from turnover are averagely 14 percent, also covering transportation abroad [54]. However, in the export industry, thus in the Nordic paper industry, average logistics costs are closer to 17 percent or even more [35]. Figure 7 shows how the percentage from turnover could increase in our case mill from 2015 onward. In this research the percentage of sea freights in logistics costs varies from country to country from 65 to 75 percent, so the change of bunker price affects differently to total transport and logistics costs. Therefore comparing counties a strong assumption is that it is very difficult to increase a turnover in the paper sector due to heavy competition in the European paper markets. Our estimation is that the Nordic bulk industry will be widely affected analogously to the paper industry because of the SECA-decision. In the middle of Europe, the mills are not really affected by the SECA, but certainly the mills in Finland and Sweden will be affected. Nevertheless, all European printing paper manufacturers have been affected by the digitalization of society since 15 years back. This seems to be an evitable process. The recent announcement provided by a large Finnish paper manufacturer informed about a close for 800 000 thousand tons in paper production in Europe in 2015. In 


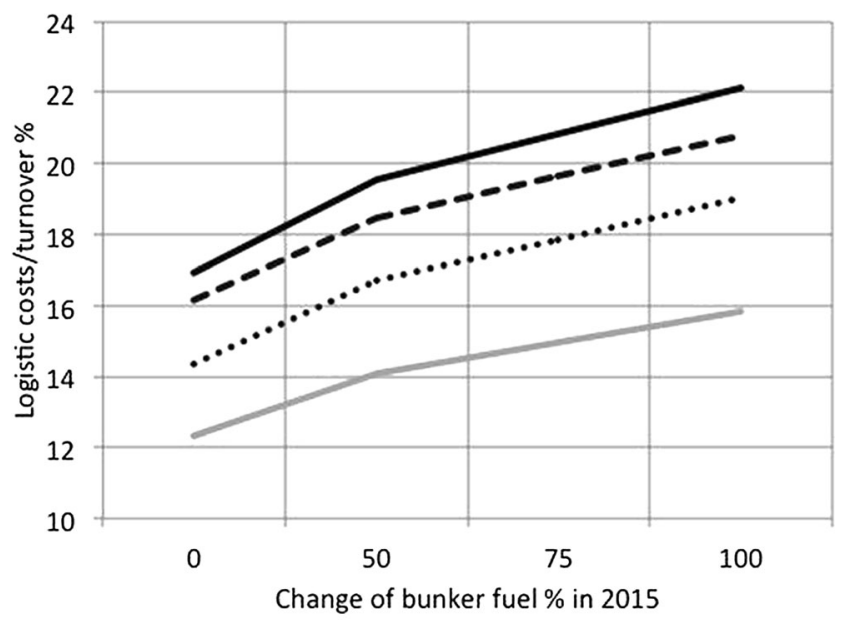

Country $1 \cdots$ Country $2-$ Country $3-$ - Country 4

Fig. 7 Change of logistics costs in \% of turnover, if bunker fuel costs increases $0,50,75$ or $100 \%$

Finland, the UPM closes 550000 tons, thus two large paper lines [61]. One reason for these closings was announced to be the lowering demand in Europe and the reduction of the variable, the logistics costs. Figure 7 highlights that transportation costs to the main markets can take over one fifth of the invoicing, if the price of bunker fuel will rise by 100 percent (country 3 ). The share of the logistics costs is not changing in linear. There seems to be a breakpoint at 50 percent. Heavy increase in fuel cost would have a direct and strong impact on logistics costs, and the bulk paper industry has very difficult time to adapt to such changes due to low margins. If fuel costs increase by 100 percent, it will have severe impacts on the Nordic paper production and sea transportation demand.

The short ferry routes to Sweden and Estonia together with truck transportation are also used, especially in transportation to East European markets and with smaller volumes to other Nordic Countries. Truck transportation is very costcompetitive in these smaller markets, and trucks from the Eastern Europe are loaded full at the mill and driven directly to customers. Short sea shipping is used in larger and more constant deliveries to Central and Southern Europe. In the paper industry delivered volumes per country can be in tens of thousands of tons, and therefore short sea shipping to larger markets in Southern Europe and the United Kingdom is considered to be a reasonable transport method. The paper companies own logistics service providers such as stevedores. In Finland, railways are used in transportation only to the Russian markets.

Margins in paper production are very low, and all the extra transport costs based on a higher fuel price are off from the margins and net profit. There is no possibility to compensate this by higher sales prices or by selling more paper to the very small domestic markets. The sea leg is an obligatory cost factor.
A highly interesting scenario is to see and forecast how the SECA-decision can impact profitability of the case site and in general, as well. Figures 8 and 9 present how the sulphur decision could impact profitability in different markets from the point of view of our case mill. Raw oil prices are estimated to stay at their present level partly due to global economical development but also due to the increased shale gas production, especially in the USA. According to the American Petroleum Institute [6], shale gas and unconventional gas production are forecasted to increase from 42 percent of total US gas production in 2007 to 64 percent in 2020. As to the cleaner MDO, which is not really known, one big question is the demand - supply balance in 2015 , and its increasing price speculations. Most of the vessels moving in the Baltic Sea will start to use the MDO in 2015, because engines will not be able to use LNG or methanol, and the HFO+scrubber technology is not considered reliable or cost-competitive in continuous use in the low-salt waters of the Baltic Sea [5]. Figures 8 and 9 address that the SECA-directive has a different impact on profitability, and this should be considered as an important finding. If fuel costs increase by 100 percent, profitability in the main market areas can drop by $30-35$ percent. The average values presented in many high-level studies on how the sulphur directive can influence the economy of industry sectors do not really reveal how negatively these environmental regulations might affect a company-level economy. The Finnish and other Nordic paper mills are using sea transport when taking their products to the European markets (four countries presented in the paper are the main markets for the case mill's production). There are not alternative modes to take paper rolls and sheets to these countries, only truck/train - short sea shipping - truck/train transportation.

Figure 9 shows how the consequences of the SECAdecision can make one large market devastatingly unprofitable

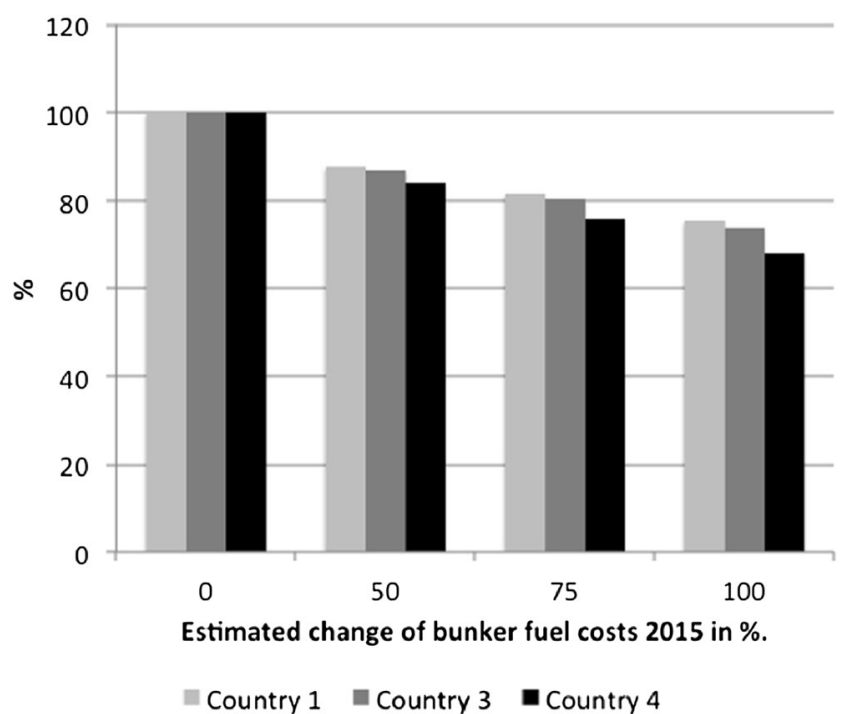

Fig. 8 Anticipated development of net profits in countries 1, 3 and 4, if fuel costs rise by $0,50,75$ or $100 \%$ 


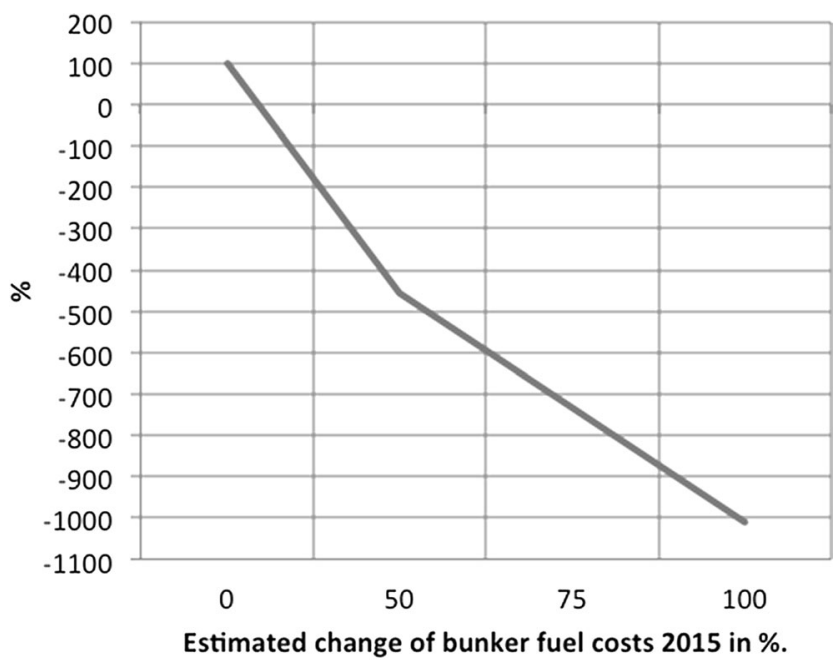

- Country 2

Fig. 9 Anticipated net profit development (\%) in country 2, if fuel costs rise by $0,50,75$ or $100 \%$

for a mill, if the worst oil price scenarios materialize. Large Nordic mills and other bulk industries are exporting products up to 100 countries globally; therefore there is a real need for profound market analysis of the demand, product prices, and the relevant cost and eco-efficient transportations means and routes. In the future, the Nordic industry must adapt by different means to serve European customers, as ecologically and costefficiently as possible, and even by relocating bulk manufacturing to more affordable places.

\section{Discussion and conclusions}

In this paper, we made scenarios on how the upcoming emission restrictions for maritime transportation (the SECAdirective) will impact the Nordic export industry. The main target of this article was to reveal how the exchange of fuel from the HFO to the MDO will impact the Nordic industry economy. We used a case study method to research and reveal impacts of the SECA-directive. The IMO [38] and The European Parliament $[23,22]$ have stated that sulphur emissions from ships must be reduced substantially in Europe, and the region where sulphur content of bunker fuel should be max. 0.1 percent was named as the Sulphur Emission Control Area. Currently vessels in the Baltic Sea can use bunker fuel, which has max. 1.0 percent sulphur content, so the new limit value is ten times less than the existing level. A problem is observed when we compare the prices of the fuels with each other. Experts [21, 47] have carried out several assumptions on how much the bunker price for the MDO will rise in 2015 compared with the HFO bunker. According to Bunkerworld [12], the current price of MDO $(0.1 \%)$ is 50 percent higher than the price of the HFO (1.0\%). Scrubber technology is not considered mature and reliable enough in the Baltic Sea environment, and the final costs of the scrubbers have also not been studied substantially (see e.g. [11]). However, recent raw oil price development during 2014 and 2015 has been positive from ship owners' perspectives: price of oil barrel is circa 50 USD (2015).

In the recent Ship Owner Barometer, about 88 percent of the ship owners announced they will use the MDO in their ships in 2015 and onward. The barometer covered 262 ships sailing in the Baltic Sea. Results of this case study strongly indicate that the sulphur directive has direct impacts on the economy of the Nordic bulk industry. When bunker fuel prices increase from year 2015 onward, it reflects directly to sea freight prices in the SECA-region. If the MDO cost were to be 100 percent more than the HFO's, it could increase the average transportation costs per ton from site to customer by more than 20 percent. The results highlight that location and transportation geography characteristics are important for the mills' results, as Arbia [7] argues.

The sulphur directive will probably indicate that from 2015 onward Central European paper mills and other manufacturing industries will benefit from outside the traditional business environment. The results of this study can be highlighted as follows:

- The impacts of the sulphur directive will vary heavily from market to market.

- Transportation costs from Finland to Europe can increase by average more than 20 percent in $€ / t$; this can also be an underestimation.

- Profitability can drop by tens of percentage due to more expensive logistics.

- The European market is not easily replaced by transporting paper products overseas due to global overcapacity of printing paper.

- Logistics costs' percentage in turnover will increase in the Nordic countries

The sulphur directive strongly affects companies' ability to stay in business, and there are some managerial implications that should be considered:

- The bulk industry should focus its efforts in building alternative logistics corridors more cost-efficient from site to end customers.

- Alternative logistics corridors from the Nordic countries should be examined.

- Affordable raw material and energy resources should be revealed to compensate new environment-based logistics costs.

In Finland and other Nordic countries there are no realistic modes to replace short sea shipping. Finland and even 
partially Sweden are more or less islands from logistics viewpoints. The paper focused to reveal how higher bunker costs would reflect to logistics costs and the paper margins, because the shipping companies are not able to adapt to the higher costs inherited with higher operating costs. The mills and shipping companies are normally making long-term agreements to secure the delivery timetables, and to have better future knowledge about the logistics costs.

The Nordic companies have been examined somewhat marginally from the point of view of the SECA-directive, and how it will affect the cost-efficiency of the industry. The continuously diminishing paper demand in Europe together with emission regulations in the shipping industry implemented by the European Parliament can bring out severe challenges for the Finnish paper producers in the near future. Additional paper machine and mill closures can be expected; they are done in order to be able to balance the supply-demand equilibrium. The large global paper companies are answering to these challenges by relocating bulk paper production from the periphery closer to the markets. This study revealed that there is clearly a need to make profound feasibility studies and academic research about the upcoming environmental decisions and their impacts on the economy and environment.

According to the Green Paper [24] new environmental directives are being planned, and they aim to lower harmful shipping emissions in addition to the existing regulations. This study addressed that there is a clear need beforehand to make profound feasibility studies and academic research about the upcoming environmental decisions and their impacts on the economy and the environment. Many actors and stakeholders have considered that the SECA-decision and its economic impacts on shipping and logistics industry and freight owners were not examined carefully before the decision was made.

Open Access This article is distributed under the terms of the Creative Commons Attribution License which permits any use, distribution, and reproduction in any medium, provided the original author(s) and the source are credited.

\section{References}

1. Acciaro, M. (2014) Real option analysis for environmental compliance: LNG and emission control areas. Transport. Res. Part D

2. Acciaro M, Nyegaard-Hoffmann P, Strandmyr Eide M (2013) The energy efficiency gap in maritime transport. J Ship Ocean Eng 25:110

3. AECOM (2011) Rail baltica, final report: volume I. AECOM Limited, Chelmsford

4. AECOM (2011) Rail baltica, final report: volume II. AECOM Limited, Chelmsford

5. Alhosalo, M. (2013) Shipowners barometer, publications from the centre for maritime studies, University Of Turku, B 197, Turku
6. American Petroleum Institute (2014) Facts about shale gas. http:// www.api.org/policy-and-issues/policy-items/exploration/facts about shale gas

7. Arbia G (2001) Modelling the geography of economic activities on a continuous space. Papers Region Sci 80:411-424

8. Æsøy, V., Einang, P.M., Stenersen, D., Hennie, E. and Valberg, I. (2011) LNG-fuelled engines and fuel systems for medium-speed engines in maritime applications. In: Proceedings of the International Conference on Fuels and Lubricants, SAE, 28 August-2 September, Kyoto, Japan

9. Ballou, R. (2001) Unresolved issues in supply chain design, Information Systems Frontiers 3/4: 417-26

10. Baxter JA, Chua WF (1998) Doing field research: practice and metatheory in counterpoint. J Manag Account Res 10:69-87

11. Bruckner-Menchelli, N. (2009) Scrubbers versus distillates, Sustainable shipping. Bunkerworld May/June, p. 24.

12. Bunkerworld (2014) Bunker prices, Rotterdam, http://www. bunkerworld.com/prices/port/n1/rtm/

13. Bunkerworld (2015) http://www.bunkerworld.com/prices

14. Cefig (2011) Guidelines for measuring and managing CO2 emission from freight transport operations, issue $1 /$ March, http://www.cefic. org/Documents/IndustrySupport/Transport-and-Logistics/Best $\%$ 20Practice $\% 20$ Guidelines $\% 20-\% 20$ General $\% 20$ Guidelines/CeficECTA $\% 20$ Guidelines $\% 20$ for $\% 20$ measuring $\% 20$ and $\%$ 20 managing $\% 20 \mathrm{CO} 2 \% 20$ emissions $\% 20$ from $\% 20$ transport $\%$ 20operations\%20Final\%2030.03.2011.pdf

15. CME Group (2014) http://www.cmegroup.com/trading/energy/ crude-oil/light-sweet-crude.html

16. Dennis R, Berry M (2000) Transportation, logistics, and the environment: managing interactions in a global economy. Eur Manag $\mathrm{J}$ 18(4):398-410

17. Drewry (2006) Annual container market review \& forecast 2006/07. Drewry Shipping Consultants Ltd., London

18. Easton G (2010) Critical realism in case study research. Ind Mark Manag 39(1):118-128

19. EIA (2015) The U.S. Energy Information Administration

20. Eisenhardt KM (1989) Building theories from case study research. Acad Manag Rev 14(4):532-550

21. European Maritime Safety Agency (2010) The $0.1 \%$ Sulphur in Fuel Requirement as from 1 January 2015 in SECAs; An Assessment of Available Impact Studies and Alternative Means of Compliance. Technical Report. European Maritime Safety Agency (EMSA)

22. European Parliament (2012) DIRECTIVE 2012/33/EU OF THE EUROPEAN PARLIAMENT AND OF THE COUNCIL of 21 November 2012 amending Council Directive 1999/32/EC as regards the sulphur content of marine fuels

23. European Parliament (2005) DIRECTIVE 2005/33/EC OF THE EUROPEAN PARLIAMENT AND OF THE COUNCIL of 6 July 2005 amending Directive 1999/32/EC as regards the sulphur content of marine fuels

24. European Commission (2013) Green paper, A 2030 framework for climate and energy policies

25. European Commission (2011) White paper: roadmap to a single european transport area - towards a competitive and resource efficient transport system. Office for Official Publications of the European Communities, Luxembourg

26. Flyvbjerg B (2006) Five misunderstandings about case-study research. Qual Inq 12(2):219-245

27. Forestindustries (2014) http://www.forestindustries.fi/statistics/TheFinnish-forest-industry-in-figures $1274 . h \mathrm{tml}$

28. Gerring J (2009) Case study research; principles and practices. Cambridge University Press, Cambridge

29. Hilmola, O.-P. (2013) Environmental and infrastructure payments and the future of road transports: case Tallinn-Warsaw, World Review of Intermodal Transportation Research 4:1: 55 
30. Hilmola O-P, Lorentz H (2012) Confidence and supply chain disruptions: Insights into managerial decision-making from the perspective of police. J Model Manag 7(3):328-356

31. House of Commmons (2012) House of Commons Transport Committee Sulphur emissions by ships. Sixteenth Report of Session 2010-12 Volume II, to be published 19 and 25 October 2011 and 24 January 2012

32. Hulskotte JHJ, Denier van der Gon HAC (2010) Fuel consumption and associated emissions from seagoing ships at berth derived from an on-board survey. Atmos Environ 44:1229-1236

33. Hämäläinen E (2014) Can slow steaming lower cost impacts of sulphur directive - shipper's perspective. World Rev Intermod Transport Res 5(1):59-79

34. Hämäläinen, E. (2014b) Sulphur directive- a new cost driver for Nordic export industry, under review

35. Hämäläinen E (2011) Cost efficiency of supply chain in a Nordic paper mill - a case study. Int J Manag 28(3):945-958

36. Hämäläinen, E. (2011b) Economic geographical analysis of the Finnish Paper Industry, Annales Universitatis Turkuensis, SER A11 - TOM. 263. Turku

37. Hämäläinen, E. (2011c) Economic geographic characteristics in the Finnish paper industry - a case study, Fennia 189:2: 63-75. Helsinki

38. International Maritime Organization (2014) http://www.imo.org/ OurWork/Environment/PollutionPrevention/AirPollution/Pages/ Sulphur-oxides-(SOx)-Regulation-14.aspx

39. Koskinen P (2009) Supply chain strategy in a global paper manufacturing company: a case study. Indust Manag Data Syst 109(1):34-52

40. Koskinen P, Hilmola O-P (2008) Supply chain challenges of NorthEuropean paper industry. Indust Manag Data Syst 108(2):208-227

41. Krugman, P. (1995) Development, geography, and economic theory returns and economic geography, The MIT Press, http://mitpress.mit. edu

42. Lewis MW (1998) Iterative triangulation: a theory development process using existing case studies. J Oper Manag 16:455-469

43. Lindstad H, Asbjørnslett BE, Jullumstrø E (2013) Assessment of profit, cost and emissions by varying speed as a function of sea conditions and freight market. Transp Res D 19:5-12

44. Lindstad H, Asbjørnslett BE, Strømman AH (2012) The importance of economies of scale for reductions in green house gas emissions from shipping. Energ Policy 46:386-398

45. McCutcheon DM, Meredith JR (1993) Conducting case study research in operations management. J Oper Manag 11:239-256

46. Notteboom T (2011) The impact of low sulphur fuel requirements in shipping on the competitiveness of roro shipping in Northern Europe. WMU J Marit Aff 10(1):63-95

47. Notteboom, T., Delhaye, E. and Vanherle, K. (2010) Analysis of the consequences of low sulphur fuel requirements, report commissioned by European Community Shipowners' Associations

48. Official Statistics of Finland (2014) Development index of manufacturing costs during 2000-9/2014 in the Finnish paper industry

49. Oil-price (2015) http://oil-price.net/index.php?lang=en

50. Osin V. N. (2011) Complex development of the Murmansk transport hub. Head of Infrastructure Development Department, Transport and communication Ministry of Murmansk Region, November 23, 2011, Murmansk, Russia
51. RISI (2014) http://www.risiinfo.com/contentgateway/pricewatch/ PriceWatch.html

52. Schinas O, Stefanakos CN (2012) Cost assessment of environmental regulation and options for marine operators. Transp Res C 25:81-99

53. Simons H (2009) Case study research in practice. Sage Publications, Thousand Oaks

54. Solakivi, T., Ojala, L., Lorentz, H., Laari, S. and Töyli, J. (2012) Finland State of Logistics. Ministry of Transport and Communications Finland and The Finnish Transport Agency, Publications of the Ministry of Transport and Communications, 25/ 2012

55. Song D-P, Dong J-X (2012) Cargo routing and empty container repositioning in multiple shipping service routes. Transp Res B 46: $1556-1575$

56. Song D, Zhang J, Carter J, Field T, Marshall J, Polak J, Schumacher K, Sinha-Ray P, Woods J (2005) On cost-efficiency of the global container shipping network. Marit Policy Manag 32(1):15-30

57. Stake RE (2000) Case studies. In: Denzin NK, Lincoln YS (eds) Handbook of qualitative research, 2nd edn. Thousand Oaks, CA, p $435-454$

58. Sweco (2012) Consequences of the sulphur directive, October, http:// www.svensktnaringsliv.se/migration_catalog/consequences-of-thesulphur-directive 533051.html/binary/Consequences $\% 20 \mathrm{of} \%$ 20the $\% 20$ Sulphur\%20Directive.

59. Swedish Forest Industries Federation (2009) Information Paper Consequences for the Pulp and Paper Industry due to New Sulphur Regulations for Ships, 18 June 2009

60. Trafi (2013) Evaluating the costs arising from new maritime environmental regulations, Transport Safety Agency, Trafi publications, 24/ 2013

61. UPM (2014) UPM introduces a new profit improvement target of eur 150 million - UPM Paper ENA plans to reduce 800,000 tonnes of publication paper capacity in 2015. http://www.upm.com/EN/ INVESTORS/Investor-News/Pages/UPM-introduces-a-new-profitimprovement-target-of-EUR-150-million---UPM-Paper-EN-001Thu-13-Nov-2014-09-30.aspx

62. Utriainen M. (2013) Trend survey on maritime transport. Finnish Transport Agency, Traffic Services. Helsinki 2013. Research reports of the Finnish Transport Agency 2, 39 pages

63. Wang S, Meng Q, Zhiyuan L (2013) Bunker consumption optimization methods in shipping: a critical review and extensions. Transp Res E 53:49-62

64. World Bank (2012) Connecting to compete, trade logistics in the global economy. The logistics performance index and its indicators, eds: Jean-François Arvis, Monica Alina Mustra, Lauri Ojala, Ben Shepherd and Daniel Saslavsky

65. World Shipping Council (2014) http://www.worldshipping.org

66. Wuisan L, van Leeuwen J, van Koppen CSA (2012) Greening international shipping through private governance: a case study of the clean shipping project. Mar Policy 36:165-173

67. Yang C-S, Lu C-S, Haider JJ, Marlow PB (2013) The effect of green supply chain management on green performance and firm competitiveness in the context of container shipping in Taiwan. Transp Res E 55:55-73

68. Yin RK (2009) Case study research, design and methods, 4th edn. Sage, London 